\title{
Towards improved coverage of Southeast Asian Englishes in the Oxford English Dictionary
}

\author{
Danica Salazar
}

Received: 26 December 2013/Accepted: 11 April 2014/Published online: 23 May 2014

(C) Springer Berlin Heidelberg 2014

\begin{abstract}
This paper examines the lexicon of Southeast Asian varieties of English and its representation in the Oxford English Dictionary (OED). It begins by describing the OED's changing editorial policies with regard to words originating from outside of Britain. It then focusses on Southeast Asian words included in the OED's third and latest edition, and on recent efforts to improve the OED's handling of this type of vocabulary. The paper concludes with a discussion of the key issues that need to be addressed to ensure adequate treatment of Southeast Asian and other World Englishes in the OED: overcoming the shortage of written resources through targeted and collaborative research programmes, providing better regional labelling through the comparative study of the lexis of national and regional varieties, and diversifying the OED's coverage of Southeast Asian Englishes by including words and meanings of more current usage, as well as lexical innovations beyond simple borrowing.
\end{abstract}

Keywords Oxford English Dictionary · Southeast Asian Englishes · World Englishes

\section{The OED and World Englishes}

Widely regarded as the most authoritative and comprehensive dictionary of the English language, the Oxford English Dictionary (OED) contains information on the meaning, history and pronunciation of over 600,000 English words, exemplified by

Communicated by Yukio Tono.

D. Salazar $(\bowtie)$

Faculty of English Language and Literature, Radcliffe Humanities, Radcliffe Observatory Quarter, University of Oxford, Woodstock Road, Oxford OX2 6GG, UK

e-mail: danica.salazar@ell.ox.ac.uk 
nearly three million quotations taken from a wide variety of sources. Today, 85 years after its first, ten-volume edition was completed, the dictionary is undergoing a complete overhaul for its Third Edition (OED3), which is available exclusively online. The current revision of the OED is a huge lexicographical undertaking as ambitious as the creation of the dictionary itself, as it involves updating text from the original volumes that has remained unchanged for several decades, in order to incorporate new historical, semantic and varietal information that recent linguistic research and modern technological innovations have made available to lexicographers (Rewriting the OED 2013).

One of the main goals of the OED revision process is to widen the geographical coverage of the dictionary. The map of the English-speaking world has changed immensely since the OED was first conceived, and what were emerging Anglophone communities in the 19th century are now well-established varieties of English with their own standards of grammar, pronunciation and lexis. Clearly, any dictionary that claims to be the foremost authority on the history of the English language needs to include the lexical repertoire of English speakers beyond Britain, the users of new varieties now known as World Englishes.

In his description of the role of World Englishes in the New Oxford English Dictionary project, Edmund Weiner, co-editor of the OED Second Edition (OED2) and the dictionary's current Deputy Chief Editor, recognized the "essentially Britocentric viewpoint" of the OED and its "patchy and incomplete coverage of varieties of English outside of Britain" (Weiner 1987, p. 32). The First Edition of the dictionary (OED1) was written under the assumption that Standard British English made up the common core of the language, and that any regional or dialectal variation lay just outside of this "nucleus or central mass of many thousand words whose 'Anglicity' is unquestioned" (Murray 1884, p. xvii). The OED's first editor, James A. H. Murray, is known to have struggled with words in the fringes of the common core-not only dialectal and foreign words, but also scientific and technical terms and slang words - ultimately deciding to include only words of this type that are "passing into common use, and approach the position or standing of 'common words"” (Murray 1884, p. xvii).

This is not to say, however, that OED1 was entirely inhospitable to words of nonBritish origin. The many thousands of World English words that entered the dictionary during Murray's editorship are evidence of his commitment to including this type of vocabulary in the OED, despite resistance from his subeditors and superiors at Oxford University Press (OUP), and criticism from consultants and reviewers (Ogilvie 2012).

In his General Explanations to OED1, Murray uses the metaphor of citizenship to describe how he categorized foreign words in English according to their degree of assimilation into the language, distinguishing between naturals, denizens, aliens and casuals (1884, p. xix). Those words that Murray classified as denizens and aliens, as well as those casuals approaching these two prior categories, were marked by two parallel lines beside the headword (II), a symbol known by the in-house term tramline. Murray himself admitted to the inherent subjectivity of his method of classification (1884, p. xix), which unsurprisingly led to a number of inconsistencies in the use of tramlines (Brewer 2007), and may even have contributed to the 
patchiness of the OED's regional coverage that Weiner (1987) acknowledged many years later. Perhaps to avoid having to make these unwieldy distinctions (Brewer 2007), the editors Charles Talbot Onions and William Craigie eliminated tramlines altogether in their 1933 Supplement (Ogilvie 2004).

The OED's coverage of World English words further expanded in the 1970s and 80 s with the publication of the four-volume Supplement edited by Robert Burchfield. Work on this Supplement began at a time when Englishes spoken in different parts of the world began to be recognized as varieties in their own right, and the OED addressed this phenomenon by surveying these new varieties in a revitalized Reading Programme (Price 2003). As the editor himself described it, "We have made bold forays into the written English of regions outside the British Isles, particularly into that of North America, Australia, New Zealand, South Africa, India, and Pakistan" (OED Supplement 1972, p. xiv). However, Burchfield's Supplement also saw a return to the use of tramlines to mark out foreign words. In addition, given the Supplement's remit of covering contemporary vocabulary, its treatment of World Englishes remained historically incomplete despite its wider geographical reach. As a consequence, the 1989 edition of the OED (OED2), being an amalgamation of OED1 and Burchfield's Supplement, combines "two methods of treating regional English [...] diachronic but limited spatially to Britain, and international but limited temporally to the present" (Weiner 1987, p. 32).

Given this imbalance and the increasing importance of non-British varieties of English on the global stage, coverage of World English vocabulary became a major concern for the editorial team working on the dictionary's current revision, as can be observed in former Chief Editor John Simpson's preface to OED3 (Simpson 2013a):

From its base in Britain, the English language has expanded over the centuries to become a world language, in which individual varieties share a common core of words but develop their own individual characteristics. [...] The English of the British Isles now becomes one (or indeed several) of these varieties, whereas previously standard British English may have been regarded as the dominant form of English.

The enormous task of internationalizing the OED is made less daunting by the fact that the editors of OED3 now have access to a wealth of information that was unavailable to editors of previous editions. A huge amount of quotation evidence is continuously being collected from a targeted, structured Reading Programme that includes a comprehensive selection of literary and non-literary texts from all over the English-speaking world. Modern technology has also made it possible for editors to consult databases, newspapers, journals and books from all corners of the globe, as well as a number of regional dictionaries and grammars. Editors are also aided by contributions from members of the public, and specialist advice from an international network of consultants. Using all these resources, OED lexicographers are now able to widen the geographical scope of the dictionary through the inclusion of new entries, and to fill the historical gaps in existing entries through the addition of antedatings and postdatings and the amendment of regional labels.

Another important dimension of the OED revision is the removal of much of the Britocentric stylistic bias that was apparent in its earlier editions (Price 2003). Once considered the default, British English is now treated as one among multiple 
varieties of English, and vocabulary items characteristic of this variety are labelled as such. Unqualified labels such as Law, History and dialect are replaced with the more specific labels British Law, British History and British regional. American pronunciations are added alongside the British, while American spellings that differ from British conventions are moved from a list of variant forms to these entries' actual headwords (Price 2003). The use of tramlines to mark alien words has also been discontinued (Ogilvie 2004).

These new practices are part of the OED team's continuing efforts to make the dictionary a truly comprehensive record of the English lexicon by giving equal and balanced treatment to words in a wide range of Anglophone settings. To highlight what has been achieved so far and what can still be done, the paper will focus on the OED's coverage of words from the Southeast Asian region, home to a diverse and complex group of World Englishes.

\section{Words of Southeast Asian origin in the OED}

In Southeast Asia, English is present in two different contexts of use: as a second language in Brunei, Singapore, Malaysia and the Philippines (Low and Hashim 2012), and as a foreign language in the rest of the region, with English being most established in the language education policies of Thailand, Vietnam and Indonesia (Bautista and Gonzalez 2006).

Singapore and parts of what is now Malaysia comprised a group of British territories known as the Straits Settlements, which was initially controlled by the British East India Company but later became a crown colony under direct British rule. The territories on Peninsular Malaysia formed the Federation of Malaya in 1948 and became independent from the British Empire in 1957. In 1963, Malaya united with Sabah, Serawak and Singapore, creating a new country named Malaysia, but Singapore seceded from the union 2 years later to establish itself as an independent city-state. Brunei was similarly a British protectorate for nearly 100 years, from 1888 until its independence in 1984. The Philippines, on the other hand, was a Spanish colony for over three centuries before it was ceded by Spain to the United States in 1898. The country remained under American control until it was granted independence in 1946.

Despite their differing colonial histories, all four post-imperial nations have maintained English in their respective systems of education, and continue to use the language alongside local vernaculars, particularly in the domains of business, government, diplomacy, science and technology. In addition to its intranational functions, English plays the role of intraregional lingua franca, as evidenced by its status as official language of the Association of Southeast Asian Nations (ASEAN).

The many years of contact between English and the other languages spoken in these countries have resulted in distinct structural and social features that form the basis of what is now recognized as Bruneian, Singaporean, Malaysian and Philippine English. The presence of linguistic substrata, or the mother tongues of Bruneians, Singaporeans, Malaysians and Filipinos who use English as a second language, has had a profound influence on the phonology, lexis, syntax and 
discourse conventions of these varieties and made them considerably different from British and American English (cf. Bautista and Gonzalez 2006 and Low and Hashim 2012 for more on the historical and socio-political background of Southeast Asian Englishes and their particular linguistic characteristics).

The lexical imprint of Southeast Asian languages on English is apparent from the very first fascicle of the OED. The first draft of this instalment, which covered the range $A$-Ant, came back to Murray with instructions from OUP Delegates to delete, among other foreign words, the Tagalog word abaca, a native word for Manila hemp (Ogilvie 2012). Murray ignored these instructions and the word remains in the dictionary to this day. Vocabulary items such as these are illustrated in OED1 by quotations dating back to as early as the 16th century, centuries before English had even reached Southeast Asia. These words are usually sourced from early specialist dictionaries and navigational and geographical accounts written by British authors, or translations into English of similar books in other languages. The first quotation for abaca, for instance, comes from Malachy Postlethwayt's translation of Jacques Savary des Brulon's Dictionnaire universel de commerce (1723-1730), while the earliest quotation source for kiack, a Burmese word for a Buddhist temple, is Richard Hakluyt's The principal navigations, voyages, traffiques and discoveries of the English nation (1598-1600).

Later quotations are provided by 19th- and 20th-century travel and science books, as well as scientific journals on a wide range of subjects. A significant number of Southeast Asian words, particularly those of Malaysian origin, made their way into Burchfield's four-volume Supplement, where they are exemplified by quotations dating from the early 19th century to around the time of the Supplement's publication. More contemporary usages have been and are being added to OED3 to provide more evidence for entries in revision and to inform the creation of new entries. Quotations for present-day Southeast Asian vocabulary are usually taken from books from or about the region, and from local English-language newspapers such as The Philippine Daily Inquirer, New Straits Times Malaysia and Sunday Times Singapore:

- blind item $n$. orig. and chiefly U.S. (b) a (scandalous) story, esp. in a gossip column, which does not reveal the names of the people being discussed.

2006 Philippine Daily Inquirer (Nexis) 23 Sept., That blind item I wrote some months ago about a PBA assistant coach being involved in cybersex should have served as a wake-up call. (Draft addition, August 2007)

- panglima, $n$. In Malaysia and Indonesia: a chief; a military commander. Also used as a title and form of address.

2001 New Straits Times (Malaysia) (Nexis) 19 Dec. 4 The group of seven scroll bearers, comprising a penghulu, two panglimas, two Chinese and two Indian representatives, handed over the scroll to the State Secretary. (Updated March 2005)

- bumiputra, $n$. and adj. Malaysian citizens of indigenous Malay origin. 1972 Sunday Times (Singapore) 24 Sept. 6/3 In the Faculty of Engineering, bumiputras now formed 7.3 per cent of the total enrolment. (Entry from 1993 OED Additions Series, volume 1, not fully updated). 
An OED word of Southeast Asian origiBudapest, eds.Gerhard Stickel andTamás Váradi, 95-110. Frankfurt amMain: Peter Lang.n is typically identified as such through the mention of its region or country of origin in its definition, as shown in the following examples (OED 2000):

- adat, $n$. In the Islamic regions of South-East Asia: custom, accepted practice; (also) customary law. (Updated December 2011)

- Baba, $n .4$ and $a d j$. In the Malaysian and Indonesian region: a person of Chinese descent whose ancestors have been long settled in the region. (Updated June 2011)

- bomoh, $n$. In Malaysia: a traditional healer; a person believed to have magical powers. Sometimes used as a title. (New entry, September 2008)

- makan, $n$. In Malaysia, Singapore, and Brunei: food, eating. (Updated June 2000)

- Moro, $n .2$ and adj. A. n.2 A Filipino Muslim; spec. a member of any of the various Muslim peoples of the southern Philippines. The Moros, whose Islamic faith was introduced to the Philippines from Borneo and Malaya in the 14th cent., account for about 5 per cent of the Filipino population. (Updated December 2002)

- pahit, $n$. In South-East Asia: a drink of gin and bitters. Also gin pahit. (Updated March 2005)

- satay, $n$. An Indonesian and Malaysian dish, consisting of small pieces of meat grilled on a skewer and usually served with a spiced sauce. (Entry from 1982 Supplement, not fully updated)

The Southeast Asian provenance of words is also made evident by their etymology, which is clearly indicated in OED entries. Philippine English words are mostly of Tagalog or Spanish origin, while most Singaporean, Malaysian and Bruneian words can be traced back to Malay. Sanskrit, Javanese and Chinese are also frequent sources of Southeast Asian English vocabulary:

- anting-anting, $n$. Etymology: Tagalog. A supposed supernatural influence having the power of protecting its possessor from harm; also, an amulet or charm having the same qualities. (Entry from 1933 Supplement, not fully updated)

- poblacion, n. Etymology: < Spanish población settlement, population, town, city, village (1238 or earlier; 1129 in sense 'emigration') < poblar (see poblador n.) + -ación -ation suffix. 1. In the Philippines: the principal community of a district; a town that is an administrative centre. (Updated September 2006)

- kampong, $n$. Etymology: < Malay kampong, kampung inclosure. A Malay village. (Entry from OED1, not fully updated)

- batik, $n$. Etymology: Javanese, lit. 'painted'. 1. The Javanese art and method (introduced into England by way of Holland) of executing designs on textiles by covering the material with wax in a pattern, dyeing the parts left exposed, and then removing the wax, the process being repeated when more than one dye is used. Also, (a garment made of) a fabric dyed in this way; the kind of pattern, consisting of a medley of colours, characteristic of this art. (Entry from 1933 Supplement, not fully updated) 
- merdeka, n. Etymology: < Malay merdeka (also in form merdeheka), Indonesian merdeka independent (used in political phrases in the mid 20th cent., e.g. in Indonesian Indonesia merdeka 'free Indonesia', and standing alone as a slogan or salutation with the meaning 'freedom' or 'independence') < Sanskrit mahardhika of great prosperity < mahā-great (see mickle adj.) $+r d d h i$ prosperity $+-k a$, suffix forming adjectives. In Malaysia and Indonesia: freedom, independence. (Updated September 2001)

- kongsi, n. Etymology: < Chinese kung-ssu (as pronounced in Hokkien) company, corporation. In Malaysia, an association or partnership, esp. an association of Chinese people. (Entry from 1976 Supplement, not fully updated)

The OED also makes use of regional labels, which are italicized designations of regional origin or geographical areas of usage. Although labels such as United States and Australia are widely used throughout the dictionary, only a few Southeast Asian words have been given region- or country-specific labels. A recent OED Online search for the label S.E. Asian returned only four entries:

- pacify, v.1. trans. c. To restore (contending parties) to a state of friendly relations; to reconcile (one person or party) with or to another. Also intr: to arrive at a reconciliation or a peaceful resolution. Now chiefly $S$. E. Asian. (Updated March 2005)

- schooling, adj.1 2. That attends school; school-going. Now chiefly Indian English, S.E. Asian, and W. Afr. (Updated March 2012)

- shop lot, $n$. Now chiefly S.E. Asian. The portion of land occupied by a shop; shop premises. (New entry, June 2007)

- void deck $n$. S.E. Asian the ground floor of a block of flats, which is left vacant, typically to be hired out for communal activities. (Draft addition, June 2007)

There is also just one entry each for the country labels Burma, Indonesia, Malaysia and Philippines in OED3:

- tamein, n. Burma. A draped garment resembling a sari, worn usu. by women. (Entry from 1933 Supplement, not fully updated)

- Kromo, $n$. Indonesia. The polite form of Javanese, used by those of lower status when addressing social superiors. (Entry from 1976 Supplement, not fully updated)

- kati, $n$. Malaysia.$=$ catty n. (Entry from 1976 Supplement, not fully updated)

- jeepney, $n$. Philippines. A jitney bus converted from a jeep. (Entry from 1976 Supplement, not fully updated)

OED Online users with no specific words in mind also have the option to browse the dictionary's regional categories, which include one for Southeast Asia. Clicking on this option takes one to a list of 315 different senses. However, a closer look at these results reveals that a large majority of them (221 out of 315) are actually South Asian usages, as the Southeast Asian search refinement option conflates these two very different regions. This leaves only a few dozen Southeast Asian entries, a number that does not at all reflect the OED's actual coverage of these English 
varieties. Many dozens of entries attributed to Malaysia (e.g., Agong, bumiputra), Singapore (e.g., Singlish, roti prata) and the Philippines (e.g., adobo, tinikling) cannot be found using the Southeast Asian search option.

\section{Improving the coverage of Southeast Asian English in the OED}

We have seen that although the OED has been receptive to words of non-British origin all throughout its long history, its coverage of World English has generally been uneven and incomplete, especially of new postcolonial varieties such as those of Southeast Asia. The team currently working on the OED's large-scale revision project has taken some important steps towards a more comprehensive treatment of Southeast Asian Englishes in the dictionary, but there remain a number of challenges to achieving this goal.

\subsection{Gathering lexical evidence}

The first important issue that needs to be addressed is one that has existed since Murray's time: the lack of textual evidence. The inclusion of World Englishes in the OED is made difficult by the comparatively short publishing history of postcolonial varieties and the limited availability of such publications in Britain. Although the Internet has given today's OED editors wider access to non-UK books and databases and almost instantaneous communication with worldwide consultants, evidence for region-specific usages is still very small compared to that for general English. The situation is further complicated by the fact that publications in postcolonial Southeast Asia are still heavily edited following British or American standards, so that lexical innovations in regional speech may not always make it to regional writing.

It is obvious that some inherent features of World English vocabulary items lead them to fail OED's assessment criteria for the inclusion of new words: they are not in the OED's quotation databases at all, they have a date range of less than 100 years, and they are hardly present in the external databases and other research resources that OED editors routinely rely on. We can conclude, therefore, that if more words from World Englishes are to be incorporated into the OED, some changes have to be made to the dictionary's selection criteria for new words to keep them from discriminating against words that are widely used in their World English variety of origin but are of restricted currency in other varieties.

The Reading Programme is one way that the OED can overcome the shortage of material, as the reading of Southeast Asian texts adds more evidence for these varieties in the dictionary's quotation databases. Another possible solution is consulting a wider range of texts that are much less given to editing and more to idiosyncratic usage, such as blogs, wikis and social media sites.

There is also a research project currently in progress at OUP and the English Faculty of Oxford University on the lexicon of Philippine English (Salazar 2013a). The project's main objective is to study how Philippine English is represented in the OED, and to fill any gaps in the dictionary's coverage of this particular variety 
through the identification of Philippine English words from available digital language corpora and the consultation of regional dictionaries and lexical surveys previously carried out by Philippine lexicologists. Some of the results of this investigation will feed directly into the OED's on-going revision and aid in improving its treatment of a specific branch of Southeast Asian English.

Another novel method of gathering lexicographical data for World Englishes is the crowdsourcing model, which is currently being piloted at Oxford Dictionaries, also with Philippine English. The Pinoy English Community Dictionary is an OUPsponsored project to collect examples of Philippine English usage, whose ultimate objective is to produce a public, online glossary of the variety of English spoken in the Philippines (Salazar 2013b). The project will also help OUP to identify Philippine words and usages for potential inclusion in Oxford's dictionaries, including not only the OED but also dictionaries of current English available on oxforddictionaries.com. This online dictionary, whose alpha version is now accessible at www.languagecommunities.com/pinoyenglish.html, aims to become a platform through which Philippine English users themselves can suggest new words and senses, and even create entries that will be searchable and viewable by the general public. The community dictionary is also supported by a dedicated Facebook fan page and Twitter feed, where calls are regularly put out to the public to submit evidence for specific words or semantic fields. This evidence can also be in multimedia form, such as photographs, audio or video showing Philippine English as it is used by native users in local contexts. A recent campaign on the community dictionary's fan page asking for Facebook users' favourite Filipino desserts yielded such typical native food vocabulary as buko pandan (a pandaninfused salad made of gelatin cubes, young coconut and cream), leche flan (the Filipino version of crème caramel), macapuno (a syrupy dessert made from a rare local variety of coconut), maja blanca (a coconut-flavoured pudding with corn kernels and toasted coconut) and turon (deep-fried banana rolls).

By linking its online platform to social media sites, the project will provide two ways in which the community can engage with the dictionary: those who have an interest in lexicography and would like to be involved in the actual creation of entries can do so through the dictionary website, while those who have less time to dedicate to the project can still be encouraged to contribute evidence through social media sites that they are already familiar with.

Targeted research programmes such as the OUP-Oxford University project on Philippine English and the Pinoy English Community Dictionary represent promising new means of supplementing OED editors' work on World Englishes. Such collaborative approaches also demonstrate the value of establishing links between OUP-based lexicographers and communities with specialized knowledge of World English vocabulary, which include scholars engaged in lexical research, as well as speakers of different varieties of English around the globe. Editorial research by OED staff draws from well over 100 years of lexicographical tradition and thus provides an invaluable etic perspective on the word stock of World English varieties. However, this needs to be complemented by insight from local informants viewing the lexis of their respective varieties from an emic standpoint. As noted by Ooi (2001), a combination of insider and outsider perspectives is indispensable to 
the accurate description of the lexicon of World Englishes, including those of the Southeast Asian region.

\subsection{Defining regional labels}

It is not enough that Southeast Asian words make it into the OED; its users should also be able to find them easily. This makes labelling another vital concern that raises a number of practical questions on how to define the regional limits of the OED. Studies have pointed to distinctive linguistic features common to Southeast Asian varieties of English (Kirkpatrick 2012), but given the many differences in colonial background, native languages and English usage patterns among nations of the region, is there enough justification for a Southeast Asian label? If not by region, should labelling then be done by country? How does the OED determine which countries deserve their own labels? What should the dictionary do with words that appear in different country-specific varieties, with different nuances in meaning in each?

Providing adequate answers to these questions requires more comparative lexical studies of World Englishes. Much work has been done on the identification of vocabulary items that characterize specific English-speaking countries or regions, but relatively little attention has been given to the comparative analysis of a set of national or regional varieties to determine whether certain words or phrases are exclusive to their variety of origin or shared by a number of different varieties. According to Wolf and Polzenhagen (2009, p. 10), "this perspective is evidently crucial to the question about whether emerging national varieties [...] can indeed be delineated on linguistic grounds, or if one may at best speak of more global regional varieties", e.g., speak of Southeast Asian Englishes instead of Philippine English, Singaporean English, etc. Comparative accounts of World English lexis are necessary not just to settle a fundamental point of theory: they can also inform the labelling policies of existing dictionaries such as the OED, and may even lead to the creation of regional lexicographic works such as a dictionary of Southeast Asian Englishes. New language research resources like the Corpus of Global Web-Based English (GloWbE, Davies 2013), which can show the frequency of a wide range of lexical phenomena in multimillion-word corpora representing the English spoken in 20 different countries (including Malaysia, the Philippines and Singapore), will facilitate the comparative study of the vocabulary of World English varieties and reveal patterns of similarities and differences, a few examples of which are shown in Table 1.

\subsection{Diversifying lexicographical coverage}

The first phase of the OUP-Oxford University project on Philippine English, which involved a survey of all Philippine-related items in the most current version of the OED, has shown that Philippine English words in the dictionary fall within one of the following categories:

- Words that are widely used in British and/or American English, or even in other parts of the English-speaking world (e.g., boondock, ylang-ylang). 
Table 1 Lexical items shared by multiple Southeast Asian varieties of English

\begin{tabular}{lllll}
\hline Word & Definition & \multicolumn{3}{l}{ Frequencies in GloWbE } \\
\cline { 3 - 5 } & & $\begin{array}{l}\text { Philippine } \\
\text { English }\end{array}$ & $\begin{array}{l}\text { Singaporean } \\
\text { English }\end{array}$ & $\begin{array}{l}\text { Malaysian } \\
\text { English }\end{array}$ \\
\hline Handphone & A mobile phone & 3 & 196 & 170 \\
Makan & Food, eating & 2 & 104 & 268 \\
Siomai/siew mai & A traditional Chinese dumpling & 85 & 46 & 20 \\
Void deck & Vacant ground floor of a block of flats & 0 & 106 & 2 \\
Wet market & Market selling fresh meat and produce & 50 & 109 & 68 \\
\hline
\end{tabular}

- Words whose widespread use is restricted to the Philippines, their country of origin (e.g., anting-anting, barangay, jeepney).

- Words that are rare, archaic, historical or scientific (e.g., medrinaque, Marcosian, ladronism, marcottage).

It can be said that these categories also apply to other Southeast Asian English lexical items included in the OED. The first category is generally well covered by the dictionary, but the second one is insufficiently represented, largely due to the problem of limited linguistic evidence discussed above. There is currently a bias towards words of the third category, which are mainly direct borrowings from local languages that refer to native flora and fauna, ethnic groups, languages and other cultural items. Bolton and Butler (2008) call these terms "Webster words": words that date back to the early years of contact between colonizers and colonized, and between English and local languages. A large number of these Webster words made their way into the OED during a time when frequency was not a criterion for inclusion in the dictionary. These words are undeniably of anthropological interest and deserve a place in a historical dictionary, but their noticeable prevalence over more contemporary lexis results in an imbalance that needs to be properly addressed.

The predominance of these so-called Webster words also contributes to the idea that World English vocabulary consists mostly of borrowings from exotic languages. This is certainly not the case, as lexical innovation in emerging varieties of English goes beyond loanwords. Southeast Asian Englishes alone use a wide range of strategies in the creation of new words, which include affixation, abbreviation, compounding, blending, clipping, conversion from one part of speech to another, loan translations, loan blends and complete semantic change. Some examples from Philippine and Singaporean English can be found in Table 2. Although they are much harder to pinpoint than borrowings, representing these other forms of lexical innovation is another way in which the OED can improve its coverage of World Englishes.

\section{Conclusions}

In its recent history, the OED has made several important changes to try to keep pace with the increasingly central role that non-British varieties of English play in 
Table 2 Examples of mechanisms of lexical innovation in Philippine and Singaporean English

\begin{tabular}{|c|c|c|}
\hline Mechanism & Philippine English & Singaporean English \\
\hline Affixation & Presidentiable (a presidential candidate) & Heaty (hot, or of a yang nature) \\
\hline Abbreviation & $C R$ (comfort room, a toilet) & $C B D$ (Central Business District) \\
\hline Compounding & $\begin{array}{l}\text { Batchmate (one who went to school the same year, } \\
\text { or batch, as another person) }\end{array}$ & $\begin{array}{l}\text { Airflown (transported by air, } \\
\text { freshly imported) }\end{array}$ \\
\hline Blending & Fil-Am (a Filipino-American) & $\begin{array}{l}\text { Singlish (an informal variety of } \\
\text { English spoken in Singapore) }\end{array}$ \\
\hline Clipping & Condo (from condominium) & Sabo (from sabotage) \\
\hline Conversion & $\begin{array}{l}\text { Adjectival use of traffic (e.g., It's traffic in Manila } \\
\text { during the Christmas season) }\end{array}$ & $\begin{array}{l}\text { Adjectival use of blur (e.g., He is } \\
\text { very blur and clumsy) }\end{array}$ \\
\hline $\begin{array}{l}\text { Loan } \\
\quad \text { translations }\end{array}$ & Go down (to get off a vehicle) & Cooling (cold, or of a yin nature) \\
\hline Loan blends & Sari-sari store (a variety store) & $\begin{array}{l}\text { Ice kachang (a dessert made with } \\
\text { shaved ice) }\end{array}$ \\
\hline $\begin{array}{c}\text { Complete } \\
\text { semantic } \\
\text { change }\end{array}$ & Salvage (to summarily execute) & $\begin{array}{l}\text { Bungalow (any detached house, } \\
\text { even with multiple storeys) }\end{array}$ \\
\hline
\end{tabular}

the Anglophone world. However, it is clear that much still remains to be done. For the OED to provide a more adequate treatment of World Englishes, it needs to: (1) modify its new words selection criteria to make them more open to region-specific usage, and supplement the comparatively smaller evidence for less widely used varieties; (2) make World English data more accessible to dictionary users by improving its labelling system; and (3) diversify its coverage of World Englishes by removing the bias towards colonial-era flora and fauna terms and exotic loanwords, and giving more attention to contemporary lexis and other types of lexical innovation beyond simple borrowing.

Given the practical limitations of the OED, what now is the way forward for World Englishes in the dictionary? The OED's goal has always been comprehensiveness and completeness, but how can this be measured in English varieties that have developed in such close contact with other languages, and have been enriched by so much borrowing and code-switching? Where does a lexicographer draw the line between what is English and what is not?

The OED's digital format has taken away the restrictions of alphabetization and enabled its users to explore the dictionary in ways beyond looking up individual words (Brewer 2004). John Simpson has noted how advances in computational lexicography have shifted the focus of interest from single word lookups to more general investigations of linguistic trends (Simpson 2013b). With this change in how users access the content of the OED, achieving coverage of a World English variety that is comprehensive enough to clearly show the patterns of lexical innovation throughout its history is becoming more important than the inclusion of any single word. For instance, as it stands at the moment, coverage of Southeast Asian Englishes in the OED makes it seem that what these varieties have added to the word store of the English language is mostly plant and animal terms, when all 
evidence shows that their contributions are much richer and more varied than this. It is apparent that a more wide-ranging selection of vocabulary that reflects the actual lexical creativity of its Southeast Asian users matters more, and is much more achievable, than any possible notion of completeness.

Providing more dynamic means of access to OED content is also crucial to giving dictionary users a vivid snapshot of the constantly evolving vocabulary of World Englishes. Displaying lexicographical information in maps and charts, and linking OED entries to external resources such as encyclopaedia articles, equivalent entries in regional dictionaries, and quotations in local publications will give users a way to further investigate the vocabulary of the Englishes of Southeast Asia and other parts of the world. By embracing World Englishes through these changes and innovations, the OED will be able to maintain its role as the leading resource for historical lexicography, not just for British English, but also for all global varieties of the language.

\section{References}

Bautista, Maria Lourdes S. and Andrew B. Gonzalez. 2006. Southeast Asian Englishes. In The handbook of World Englishes, eds. Braj Kachru, Yamuna Kachru, and Cecil Nelson, 130-144. Oxford: Blackwell Publishing.

Bolton, K. and Susan Butler. 2008. Lexicography and the description of Philippine English vocabulary. In Philippine English: linguistic and literary perspectives, eds. Ma. Lourdes S. Bautista and Kingsley Bolton, 175-200. Hong Kong: Hong Kong University Press.

Brewer, Charlotte. 2004. The "electronification" of the Oxford English Dictionary. Dictionaries: Journal of the Dictionary Society of North America 25: 1-43.

Brewer, Charlotte. 2007. Treasure-house of the language: the living OED. New Haven, London: Yale University Press.

Davies, Mark. 2013. Corpus of global web-based English: 1.9 billion words from speakers in 20 countries. http://corpus2.byu.edu/glowbe/.

Kirkpatrick, Andy. 2012. Theoretical issues. In English in Southeast Asia: features, policy and language in use, eds. Ee Ling Low, and Azirah Hashim, 13-31. Amsterdam: John Benjamins.

Low, Ee Ling, and Azirah Hashim (eds.). 2012. English in Southeast Asia: features, policy and language in use. Amsterdam: John Benjamins.

Murray, James A. H. 1884. General explanations. In A new English dictionary on historical principles: Part 1: A-Ant, xvii-xxiv. Oxford: Oxford University Press.

Ogilvie, Sarah. 2004. From "outlandish words" to "World English": the legitimization of global varieties of English in the Oxford English Dictionary (OED). In Proceedings of the Eleventh EURALEX International Congress, 651-658. Lorient, France: EURALEX.

Ogilvie, Sarah. 2012. Words of the world: a global history of the Oxford English Dictionary. Cambridge: Cambridge University Press.

Ooi, Vincent. 2001. Globalising Singaporean-Malaysian English in an inclusive learner's dictionary. In Who's centric now? The present state of post-colonial Englishes, ed. Bruce Moore, 95-121. Oxford: Oxford University Press.

Price, Jennie. 2003. The recording of vocabulary from the major varieties of English in the Oxford English Dictionary. In The politics of English as a world language: new horizons in postcolonial cultural studies, ed. Christian Mair, 119-137. Amsterdam: Rodopi.

Rewriting the OED. 2013. http://public.oed.com/the-oed-today/rewriting-the-oed. Accessed 29 Nov 2013.

Salazar, Danica. 2013a. Beyond boondocks: Pinoy words in the Oxford English Dictionary. Blog entry. http://pinoywords.wordpress.com/2013/04/04/beyond-boondocks-pinoy-words-in-the-oxford-english-dictionary. Accessed 29 Nov 2013. 
Salazar, Danica. 2013b. Philippine English on the cutting edge of World English lexicography. Paper presented at the Philippine English Symposium, De La Salle University, Manila, Philippines. 14 September 2013.

Simpson, John. 2013a. Preface to the third edition of the OED. http://public.oed.com/the-oed-today/ preface-to-the-third-edition-of-the-oed. Accessed 29 Nov 2013.

Simpson, John. 2013b. Mediums of access to the Oxford English Dictionary. In Lexical challenges in a multilingual Europe: Contributions to the Annual Conference 2012 of EFNIL in Budapest, eds. Gerhard Stickel and Tamás Váradi, 95-110. Frankfurt am Main: Peter Lang.

Supplement to the Oxford English Dictionary, 4 vols. 1972-1986. Oxford: Oxford University Press.

The Oxford English Dictionary, 3rd edn. 2000. http://www.oed.com. Accessed 29 Nov 2013.

Weiner, Edmund. 1987. The new OED and World English. English Today 3(3): 31-34. (Reprinted from English World-Wide 7:259-266).

Wolf, Hans-Georg, and Frank Polzenhagen. 2009. World Englishes: a cognitive sociolinguistic approach. Berlin: Mouton de Gruyter. 